\title{
Study of the existing problems and public consciousness of the in-service military officers in Royal Thai Armed Forces Headquarters
}

\author{
Supawadee Meepien ${ }^{1 \mathrm{a}}$, Archanya Ratana-Ubol ${ }^{2}$, and Chularat Petcharawises ${ }^{1,2}$ \\ ${ }^{1}$ Armed Forces Security Center, 17 Ramindra, Ramindra Road, Donmuang District, Bangkok. \\ 10220, Thailand. \\ ${ }^{2}$ Department of Lifelong Education, Faculty of Education, Chulalongkorn University, 254 Phayathai \\ Road, Wangmai, Pathumwan, Bangkok 10330, Thailand.
}

\begin{abstract}
The public consciousness is an important characteristic which requires serious enhancement in Thailand. The objective of this study is to examine the existing problems and the public consciousness of the inservice military officers. As a result shows, there is currently no precise training system for public consciousness training at the Royal Thai Armed Forces Headquarters. The tasks are carried out by the chain of command. A study of the existing problems and the public consciousness could lead to the development of a training model to enhance public consciousness. If the in-service military officers, who would return to their hometown all over the country after being discharged, were to have public consciousness characteristics as a foundation for everyday life, the nation would head up the force to help society.
\end{abstract}

Keywords: public consciousness; in-service military officer

\section{Introduction}

Materialism is one of the critical problems in Thai society. People prioritize owning things over having a spiritual mind [1]. We can observe the behavior of some people in society who take advantage of others rather than thinking of public utilization of resources to the public. People compete to earn more and more to the point that virtue and morality of the people have declined.. This may indicate that Thai people now lack public consciousness [10]. Community is weakening. It can be seen in everyday life. One example is the way that some individuals claim "ownership" of the public footpaths for themselves and their own monetary gain. Another example is throwing tissue in the public toilets and leaving toilet seats dirty. These acts cause problems for others [7]. Public consciousness is an important characteristic which needs serious improvement because it

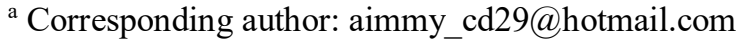


would propel social responsibility. Public consciousness is essential, in both community level and national level. Since it is knowledge and understanding of reasonable thinking, a sense of ownership in a public share, an awareness of the rights and duties without exploiting others, including to maintain a common public benefits, as well as taking care of disadvantaged person as appropriate without contrary to the common laws.

The military has a great responsibility in maintaining national security and help relieve the misery of the people [9]. One of the most important groups in the military is the inservice military officers. In former times, this group was the first to fight the "enemies" in the battlefield. Now it could be considered just as important as the first group who will be first in the field to help the community when there is a critical situation. For example, after the tsunami in 2004 and Thailand's great flood in 2011, the in-service military officers were the first group to go and assist people in the critical areas. In-service military officer is a unit of military. Enhancing public consciousness of In-service military officer is also one of the 12 core values. The Thai government has announced the 12 core values of as they want to foster characteristic which considered to be important and necessary for Thai people. Instead of relieving the misery of people, there were some in-service military officers caused the misery by themselves such as in-service military officer of Army Air Defense Command whom being accused by Min Buri Provincial Court, for the offense of premeditated murder [4], etc. Thus it can be assumed that in-service military officers were lacked of public consciousness. He could not discern what was right or wrong, what he should do or should not do. This showed that in-service military officers were not aware of the social problems. According to the study, there is none of the research, focusing on improving public awareness of in-service military officer. Therefore our research would like to emphasize such problems, to understand the conditions and the actual level of public consciousness of in-service military officer, in order to develop them to be the productive citizens who maintain good life and concern for public and national benefits, not the trouble making and social burden.

\section{Methodology}

This is a qualitative study conducted by analyzing documents and using in-depth interviews with the commander of a trained unit and a military trainer to examine their training model. However it is also a quantitative study with the use of a questionnaire given to the in-service military officers to identify the public consciousness level of in-service military officers.

\section{Result and Discussion}

Thai men at the age of 18 years old must report to military bases. Once selected, they pass through the processes of joining the armed forces. The officers will be trained for certain skills or characteristics. The important skills and characteristics include military characteristics, postures and manners. traditions, love for the nation, religion, and the king, and knowledge of democratic ideology, discipline and citizenship. What seems to be lacking is self responsibility, social responsibility, and public consciousness.

Thai men 18 years of age must be registered to be an in-service military officer. After examination and the selection process, military officers learn to be a soldiers. The new inservice military officers begin toning their bodies and minds from living as civilians to being soldiers. The main objectives are: 
1) To understand the features and gestures of the soldiers to improve our familiarity with military life, as well as to learn how to behave in order to live and work together within the military.

2) To understand the traditions of the military. It is required to maintain military characteristic $t$ all times to serve as a military officer while being a military reservist.

3) To cultivate their minds to have good morals and ideals of patriotism and religion and a democratic system with the king as head of state.

4) To foster good manners and discipline, and to be good citizens of the country. They also aim to be respected by the public and later serve as leaders after being discharged from the military.

5) To enhance a healthy body to endure the arduous and patient work and also perform in various functions within the whole military.

The duration of the in-service military training can be divided as follows:

During the first to the third months the officers aim to learn the general military subjects to obtain knowledge of communication, use maps and a compass, learn how to provide first aid and good hygiene, keep informed with basic military news, learn how to disarm a bomb and protect nuclear weapons, and use weapons. They also learn about combat operations as individuals and as a group, employing camouflage and concealment, knowing the characteristics of the soldiers, military courtesy, military morals and discipline, and to be good citizens to love and defend the country.

During the fourth to the sixth months, they learn the specific duties of the agencies to be able to operate according to the requirements of the unit.

During the seventh to the eighteenth months they go to work in the unit itself.

When they later have six months to two years left before their discharge, the in-service military officers will be discharged to return to their homeland. They can choose to study general education and/or vocational education depending on their interests and individual knowledge. The general education and vocational education have been provided courtesy of the Ministry of Education and Ministry of Labor to supply teachers and trainers to the training. The in-service military officers finish their compulsory education and also gain vocational training in various fields such as agriculture, industry and service to the profession. Moreover, They will gain knowledge in areas including democracy, civics and leadership, hygiene, health, nutrition, family planning, disaster prevention, drug abuse resistance, and conservation of national culture and art and antiques [3].

In addition, from the interviews with the commander of the trained units, there was no precise training system of public consciousness for the Royal Thai Armed Forces. The training depended on the lecturers alone who were responsible for this course. In-service military officers still lacked of awareness in real situations. They tended to follow the line of command, thus lacked learning collaboratively. They did not gain awareness of public consciousness. These results are only from the qualitative study. A report of the quantitative results is still in progress.

As a result, the in-service military officers have no awareness in real situations. The work is carried out by the chain of command. There tends to be a lack of collaboarative learning exercises. Therefore, there is no real practical application of public consciousness. However, persons with public consciousness are able to solve problems by themselves even when it impacts themselves or the broader public. They have to be confident that can solve problems by learning together [6]. The public consciousness can force people to be united in action and spirit [5]. Military officers are adults, thus their training falls under adult learning which focuses on activities and experiences rather than learning through theory. Once adults do things by themselves, it will lead to the goals of individual learning [8]. When the researcher studied the concepts of service learning of Belisle and Sullivan [2], they found that service learning is a model of experiencing learning by using activities 
that bond the human learning needs and community needs together in a reflective form to achieve the desired results. The model of public consciousness should start from learning through experience. This will make adults modify learn valuable knowledge which can be put to practical use. If a person becomes more aware in the field then it will act for the benefit of people and an environment around them [11].

\section{Conclusion}

As a mentioned before, the in-service military officer should have public consciousness which is an important characteristic for helping people in social and country. The researcher thinks that the study of the existing problems and public consciousness would lead to the development of the training model to enhance public consciousness for the inservice military officers. The concept will be service learning, adult education, training, and public consciousness. The researcher believes that if the in-service military officers have public consciousness characteristic as a foundation for everyday life, the nation will spread up the force to help the society everywhere. This will prevent the community through critical situations, which may occurs in the future.

\section{Remark}

This article is a part of "Development of A Training Model Based on Adult Learning and Service Learning Concepts to Enhance the Public Consciousness of In-Service Military Officers of Royal Thai Armed Forces Headquarters" research.

\section{References}

1. Amatyakul, Kiatiwan. Stop Global Warming with Prout. Bangkok Thailand : Parbpim Printing, 2008.

2. Belisle, Kristine and Elizabeth Sullivan., Service Learning Lesson Plans and Projects. Amnestry International and Human Rights Education Associates, 2007.

3. Kleawprodtook, Preecha. An Adaptation of In-Service Military Officer to Add a Role in Development of The Country. An Individual Research Document of The National Defence Course in year 1992-1993

4. Kongsaptho, Woratat http://m.dailynews.co.th/News.do?contentld=96877 .[online].

source:

5. Oslan, A., Blekher, L., Chesnokova, V. Public consciousness. [Online]. Available from : http://old.russ.ru/ds/english.htm[2010,January 4], 2000.

6. Poungsomlee, Anuchat. Citizans of Thailand at the century turning point. Bangkok :Civicnet Institut, 2000.

7. Ponkum, Danucha .Research and Development of Public Mind Enhancement Curriculum Based on Social Meliorism Theory for Elementary School Student. Education Dissertation of Curriculum and Instruction .Chulalongkorn University, 2012.

8. Ratana-Ubol, Archanya. Development Learning and Activities for Adults .Department of Department of Education Policy, Management, and Leadership. Chulalongkorn University, 2008.

9. Royal Thai Armed Forces Headquarters. Royal Thai Armed Forces Headquarters Policy [online] Source: http://www.rtarf.mi.th/nayoby.htm, 2012.

10. Sangarun, Keatisak., Guidelines for The Development of Thai Youth Public Consciousness: A Case Study of Groups and Networks of Youth for Public 
Consciousness. Education Thesis of Development Education .Chulalongkorn University, 2008.

11. Singhapol, Sompong. Teaching Techniques of Colaborative Learning Simajarn Journal. 3, 25 (November-March, 41-43, 1999A) 